Research Note

\title{
Vegetation Composition and Nutritional Quality of Forage for Gazelles in Eastern Mongolia
}

\author{
Kirk A. Olson, ${ }^{1}$ Martyn G. Murray, ${ }^{2}$ and Todd K. Fuller ${ }^{3}$ \\ Authors are ${ }^{1}$ Conservation Biologist and ${ }^{3}$ Professor, Department of Environmental Conservation, 160 Holdsworth Way, University of Massachusetts, \\ Amberst, MA 01003-9285, USA; and ${ }^{2}$ Herbivore Ecologist, Institute of Evolutionary Biology, University of Edinburgh, West Mains Road, \\ Edinburgh EH9 3JT, United Kingdom.
}

\begin{abstract}
Mongolia's Eastern Steppe is one of the largest remaining temperate grassland ecosystems and is habitat for Mongolian gazelles (Procapra gutturosa). During four surveys, we quantified vegetation composition, forage quality, and trace elements to gain insights on characteristics of forage that could be influencing how gazelles are distributed across the steppe. Grasses made up between $57 \%$ and $68 \%$ of all species, Stipa spp. (24-42\% of all grasses) being the most abundant. Forbs made up $6 \%$ to $23 \%$ of all species with Allium spp. (11-44\% of all forbs) the most abundant. The shrubs and dwarf shrubs were least common $(7 \%$ and $12 \%$ of all species) with Artemisia frigida Willd. (18\% and $47 \%$ of all shrubs) most common. Spring crude protein values of green vegetation averaged $21.9 \%$. Considered an important forage for gazelles, Stipa spp. was below optimum value in phosphorous (P) and magnesium (Mg). The forbs Allium spp. and Astragalus spp. and the dwarf shrub Artemisia frigida had some of the highest crude protein contents and were above optimum for all important elements (except $\mathrm{P}$ in Astragalus). Calcium $(\mathrm{Ca})$ and the Ca:P ratio were above optimal at nearly all sites surveyed. Phosphorus levels in vegetation were $96 \%$ of minimum requirements for ungulates at maintenance whereas magnesium and calcium were $113 \%$ and $145 \%$ of minimum requirements for ungulates, respectively. Magnesium and phosphorous were below values considered optimal for lactation and bone development at $78 \%$ and $71 \%$ of sites, respectively. Gazelles likely satisfy their nutrient requirements by selectively foraging on species that contain high concentrations of critical minerals. During periods of peak demands, particularly calving and postcalving periods, regions with a high abundance of forbs commonly occurring in gazelle diets (Allium and Astragalus) might be of greater value to lactating females and growing calves and, therefore, sought out.
\end{abstract}

\section{Resumen}

La estepa este de Mongolia es uno de los ecosistemas más grandes de pastizales templados que aún quedan en el mundo y es el habitad para la gacela mongoliana Procapra gutturosa. Cuantificamos en cuatro evaluaciones la composición de la vegetación, calidad forrajera y elementos traza para comprender mejor las características del forraje que pueden influenciar la distribución de las gacelas a través de la estepa. Los pastizales están compuestos entre $57 \%$ y $68 \%$ de todas las especies de Stipa spp (24$42 \%$ del total de los pastos) y es el más abundante. Las herbáceas componen del 6 al $23 \%$ del total de las especies siendo Allium spp. (11-44\% del total de todas las herbáceas) la más abundante. Los arbustos y arbustos pequeños fueron los menos comunes ( $7 \%$ y $12 \%$ del total de las especies). El Artemisia frigida Willd. (18\% y $47 \%$ del total de todos los arbustos) es el más común. Los valores de proteína cruda de la vegetación en verde durante primavera promediaron $21.9 \%$. Considerados un importante forraje para gacelas, Stipa spp., estuvo por debajo del valor optimo en fosforo (P) y magnesio (Mg). Las herbáceas Allium spp. y Astragalus spp. y un arbusto pequeño Artemisia frigida tuvieron el valor más alto en contenido de proteína cruda y estuvieron por encima del valor óptimo de todos los elementos importantes (excepto P en Astragalus). Calcio (Ca) y la relación Ca:P fue superior al valor óptimo en casi todos los sitios evaluados. Niveles de fósforo en la vegetación fueron $96 \%$ de los requerimientos mínimos para el mantenimiento de ungulados, mientras que magnesio y calcio fueron $113 \%$ y $145 \%$ de los requerimientos mínimos para ungulados, respectivamente. Magnesio y fósforo estuvieron por debajo de los valores considerados óptimos para lactación y desarrollo óseo en $78 \%$ y $71 \%$ de los sitios, respectivamente. Las gacelas probablemente satisfacen sus requerimientos nutricionales mediante el consumo selectivo de especies que contienen altas concentraciones de minerales indispensables. Durante periodos de alta demanda, especialmente periodos de parto y post parto, regiones con una alta abundancia de herbáceas están presentes frecuentemente en las dietas de las gacelas (Allium y Astragalus) y pueden ser de mayor valor para las hembras lactantes y terneros en crecimiento y por lo tanto son los más consumidos.

Key Words: forage value, grazing ecosystem, nutrient requirements, plant-herbivore interactions, Procapra gutturosa, ungulate ecology

Research was funded by the United Nations Development Programme/Global Environment Facility/Government of Mongolia "Eastern Steppes Biodiversity Project," Disney Conservation Fund, Wildlife

Conservation Society (WCS), and an anonymous donor. K.A.O. was provided additional funding by a grant from the National Science Foundation $(0743557,0743385)$.

At the time of research, Olson was a research fellow at the Wildlife Conservation Society, 2300 Southern Boulevard, Bronx, New York, NY 10460, USA.

Correspondence: Kirk A. Olson, 160 Holdsworth Way, Dept of Environmental Conservation, University of Massachusetts, Amherst, MA 01003, USA. Email: kirk@@eco.umass.edu

Manuscript received 8 September 2009; manuscript accepted 22 May 2010. 


\section{INTRODUCTION}

The nutritional demands of grassland ungulates vary with changing physiological demands for body maintenance, bone growth, weight gain, pregnancy, and lactation. Further, forage nutrition changes with seasonal environmental fluctuations in climate and vegetation. The need to fulfill nutritional demands is an important driver of many ungulate life history strategies with respect to their distribution and movements throughout the year (McNaughton 1988, 1990; Van Soest 1994; Murray 1995). An animal's failure to meet minimum nutritional requirements will result in weight loss, reduced fertility, decreased milk production, and lowered reproductive rates, as well as a weakened immune system, resulting in greater susceptibility to infectious diseases and parasites (National Research Council 1985). Deficiencies in specific nutrient requirements are known to dictate the distribution of ungulates in Serengeti grasslands (McNaughton 1990; Murray 1995), and herd movements and habitat choice are associated with seasonal variations in grass swards of short or intermediate biomass with distinctive nutritional properties (e.g., Wilmshurst et al. 1999), such as mineral composition of leaves (McNaughton 1988; Murray 1995).

The Mongolian steppe east of the Gobi Desert is one of the largest and least fragmented grassland ecosystems in the world (Yu et al. 2004a; Suttie 2005). It is also habitat for one of the few remaining large ungulate populations to occur at high density in Asia ( 1.2 million; Olson 2008), the Mongolian gazelle (Procapra gutturosa). In order to satisfy nutritional demands and in response to the need to access constantly changing forage conditions, Mongolian gazelles undertake long-distance nomadic movements (Mueller et al. 2008; Olson et al. 2010) and incorporate an intermediate feeder strategy, selecting a greater proportion of grasses and forbs during the summer and dwarf shrubs in the winter (Jiang et al. 2002b, 2003).

Vast and isolated, these grasslands were largely unknown except for descriptions by western explorers along trade routes (Campbell 1903), and from collecting and plant community mapping expeditions (Gunin et al. 1999). Recent studies have included efforts to measure biomass in Inner Mongolia (summarized by Ni 2004), estimation of biomass and crude protein by remote sensing (Kawamura et al. 2003), grassland phenology (Yu et al. 2004a, 2004b; Boone et al. 2007), effects of habitat degradation on carbon storage (Zou et al. 2007), and relationships between primary productivity and gazelle movements (Ito et al. 2006; Mueller et al. 2008). Inner Mongolia has received a great deal more attention (see $\mathrm{Hu}$ et al. 1992) but there is much difference in intensity of anthropogenic disturbance between the two regions.

Despite these efforts, there remains little quantification of the composition and nutritional value of vegetation of the Mongolian steppe. The purpose of this study was to provide a quantitative description of vegetation composition of the Mongolian steppe as it relates to forage and nutritional requirements of Mongolian gazelles. The main objectives are to provide a description of general soil and vegetation qualities across the steppe in addition to providing forage quality data of a selection of commonly occurring species or those that are known to be consumed frequently by Mongolian gazelles. Based on the findings presented, attention is drawn to the need for additional information about the patchy distribution of vegetation qualities across the steppe in order to guide conservation planning for this rare population of migratory gazelles.

\section{METHODS}

\section{Study Area}

Our study area is in the southeastern-most $80000 \mathrm{~km}^{2}$ of the approximately $275000-\mathrm{km}^{2}$ Eastern Mongolian Steppe. The region is characterized by lightly rolling hills and broad flat depressions with elevations between $580 \mathrm{~m}$ and $1780 \mathrm{~m}$ above sea level (Gunin et al. 1999). The climate is extreme continental with January and July average temperatures ranging from $-24^{\circ}$ to $+19^{\circ} \mathrm{C}$ (Olson et al. 2005a). Precipitation occurs mostly in the form of rain in late summer $(\sim 24 \mathrm{~cm})$ and snow in winter ( $\sim 13 \mathrm{~cm}$; Gunin et al. 1999). Soils predominantly are partially alkaline sandy loam (Gunin et al. 1999).

Humans and livestock have occupied the steppe in their current semi-nomadic context for the past 4000 yr. Recent socioeconomic changes resulted in a more sedentary culture with higher concentrations of grazing around population centers (Humphrey and Sneath 1999). Grass fires are estimated to occur over a majority of the study area at least once every 5 yr (Erdensaikhan and Erdentuya 2002). The ecological integrity of the Mongolian steppe is threatened by mining activities, barriers to movement (Ito et al. 2005; Olson et al. 2009b), oil extraction (Olson et al. 2009a), and unsustainable hunting (Wingard and Zahler 2006).

\section{Survey and Analysis}

Data on vegetation composition and phenology were collected while conducting four driving surveys from 2000 to 2002 (Olson et al. 2005b; Mueller et al. 2008). Two autumn (autumn 2001: 27 September-10 October; autumn 2002: 26 August-6 September) and two spring (spring 2000: 15 May-2 June; spring 2002: 19-31 May) surveys were conducted along six north-south transects varying from $75 \mathrm{~km}$ to $350 \mathrm{~km}$ in length and spaced $60 \mathrm{~km}$ apart.

During each survey vegetation data were collected at sampling stops made at $25-\mathrm{km}$ intervals along transects. Exact transect paths were the same for each survey, but due to changes in travel direction and initial start point for each survey, sampling locations along transects were different each time.

At each sampling point, a 32.5-degree single-pin point frame was used to record vegetation composition. A pin was passed at 1-m intervals until a minimum of 25 total intercepts was reached and bare ground was contacted. With each vegetation intercept, we identified common forbs to species and grass and shrubs to genera (Grubov 1982). We differentiated green from dead standing vegetation. Litter was classified as dead vegetation not attached to a living plant. Bare ground was recorded when a point frame contained no vegetation intercepts from start to ground level.

During the spring 2002 survey we clipped and saved all green vegetation $0.5 \mathrm{~cm}$ from the surface in $1-\mathrm{m}^{2}$ plots at each vegetation collection point. Immediately upon clipping, vegetation was stored in paper bags and allowed to pre-dry in the sun. Crude protein $(\mathrm{CP})$ was determined using the Kjeldahl 
method (Association of Official Analytical Chemists 1999, reference code 984.13), and neutral detergent fiber using the filter bag technique (Van Soest et al. 1991). Forage minerals considered important for herbivores (Ca, P, K, Mg, Na, Fe, Zn, $\mathrm{Cu}, \mathrm{Mn}, \mathrm{Mo}, \mathrm{Co}$ ) were analyzed using a Thermo Jarrell Ash IRIS Advantage $\mathrm{Hx}$ Inductively Coupled Plasma Radial Spectrometer (a more detailed description is available at www.dairyone.com/Forage/Procedures).

Additionally, we sampled the top $10 \mathrm{~cm}$ of soil from the center of each plot. Soil samples were analyzed for $\mathrm{pH}$ and available mineral content $(\mathrm{Ca}, \mathrm{P}, \mathrm{K}, \mathrm{Mg}, \mathrm{Fe}, \mathrm{Zn}, \mathrm{Cu}, \mathrm{Mn}, \mathrm{Co}, \mathrm{B}$, and $\mathrm{S}$; Agro Services International, www.agroservicesinternational. com/index.html). Pearson's product moment correlation was used to assess correlation between vegetation variables and soil mineral content.

\section{RESULTS}

\section{Phenology}

Spring vegetation cover was $37 \pm 22 \%(n=59)$ in 2000 and $51 \pm 23 \%(n=55)$ in 2002. Autumn vegetation cover was $47 \pm 20 \%(n=56)$ in 2001 and $79 \pm 15 \%(n=54)$ in 2002 . The two spring surveys overlapped in timing, and green (vs. standing dead) vegetation during that period (15 May-8 June) ranged between $47 \pm 34 \%(n=59)$ and $66 \pm 21 \%(n=55)(2000$ and 2002), whereas the autumn surveys were separated by nearly a month (2001 from 27 September to 10 October; 2002 from 26 August to 6 September), and green vegetation differed greatly ( $19 \pm 22 \%$ vs. $58 \pm 20 \%$; $n=56$ in 2001 and 54 in 2002) indicating that the growing season, although some vegetation remained green into October, was effectively over by late September. Stipa spp. was the most abundant grass species encountered $(24-42 \%$ of total grass cover), indicating light to moderate grazing pressure across the study area. Allium spp. were the most common forb species (11-44\% of total), and Artemisia frigida Willd. the most abundant dwarf shrub (18-47\%; Table 1).

\section{Soil Nutrients}

Soils with $\mathrm{pH}>7.0$ (alkaline) occurred at $27 \%(n=15$ of 55$)$ of the spring 2002 sites. Average soil nutrient levels were below minimum optimal requirements for plant growth, particularly for phosphorous, magnesium $(\mathrm{Mg})$, and potassium $(\mathrm{K} ; 5 \%$, $32 \%$, and $5 \%$ of minimum, respectively), although calcium was well above minimum (1040\%; Table 2). Soil element concentrations were found to be below optimum at more sites than forage element concentrations, and did not appear to affect plant species' ability to accumulate nutrients.

\section{Forage Nutrients}

On the whole, spring 2002 forage samples had a C:P ratio greater than 2:1 (the ratio considered optimum for developing bone in calves and lactation by mothers [Van Soest 1994; Underwood and Suttie 1999]) at $87 \%$ of 47 sites, and averaged values were $157 \%$ of the optimal nutritional ratio (Table 2 ). Calcium levels in forage were above minimum at $89 \%$ of 49 sites and averaged $145 \%$ above the minimum requirements (Table 2). Based on minimal marginal values for mineral requirements for ruminants (Van Soest 1994), average overall
Table 1. Abundance of vegetation types and genera $(\%$ of hits calculated from the number of contacts with a point frame) in the eastern steppe during spring and autumn surveys. ${ }^{1}$

\begin{tabular}{|c|c|c|c|c|}
\hline & \multicolumn{2}{|c|}{ Spring } & \multicolumn{2}{|c|}{ Autumn } \\
\hline & 2000 & 2002 & 2001 & 2002 \\
\hline Graminoids & $87 \%$ & $81 \%$ & $74 \%$ & $67 \%$ \\
\hline Stipa spp. & 24 & 40 & 35 & 42 \\
\hline Leymus chinensis (Trin.) Tzvel. & 21 & 19 & 8 & 12 \\
\hline Carex spp. & 19 & 17 & 16 & 14 \\
\hline Cleistogenes squarrosa (Trin.) Keng & 11 & 19 & 27 & 21 \\
\hline Other & 25 & 4 & 14 & 10 \\
\hline Forbs & $6 \%$ & $9 \%$ & $13 \%$ & $23 \%$ \\
\hline Allium spp. & 31 & 44 & 11 & 18 \\
\hline Potentilla spp. & 8 & - & 6 & 3 \\
\hline Gallium verum Linn. & 8 & - & 6 & - \\
\hline Astragalus spp. & 4 & - & 5 & 2 \\
\hline Seratula spp. & 4 & 4 & - & 3 \\
\hline Stellera spp. & - & - & - & 2 \\
\hline Others & 46 & 52 & 78 & 72 \\
\hline Shrubs & $7 \%$ & $10 \%$ & $13 \%$ & $10 \%$ \\
\hline Artemisia frigida Willd. & 47 & 25 & 22 & 18 \\
\hline Artemisia spp. & 25 & 8 & 27 & 21 \\
\hline Caragana stenophylla Pojark. & 19 & 42 & 17 & 35 \\
\hline Caragana microphylla Lam. & 9 & 15 & 9 & 10 \\
\hline Glycyrrhiza uralensis Fisch. & - & - & 2 & 1 \\
\hline Ephedra sinica Stapf & - & 8 & 17 & 5 \\
\hline Salsola spp. & - & - & 6 & 10 \\
\hline Others & - & 4 & - & - \\
\hline
\end{tabular}

${ }^{1}$ Number of standing vegetation contacts $(M$ ) during each survey: spring $2000=434$; spring $2002=520 ;$ autumn $2001=503 ;$ autumn $2002=812$.

forage quality was deficient in 4 of 10 trace elements evaluated at a majority of sites (magnesium [76\% of samples at 42 sites below minimum], phosphorous [60\% at 33 sites], sodium [ $96 \%$ at 53 sites], and zinc [ $62 \%$ at 34 sites]).

Greatest CP content in forbs or graminoids was found in Allium spp., which also had above marginal levels for all other elements (potassium being almost six times the marginal minimum and phosphorus two times the marginal minimum; Table 3). Astragalus spp. had the greatest levels of calcium and highest Ca:P ratio. Artemisia frigida Willd. had lower than average protein content but exceeded marginal requirements for all other critical elements. Stipa spp. had the lowest CP percentage of grass species samples $(15.9 \%)$. Leymus chinensis (Trin.) Tzvel. had the highest levels of sodium but was low in calcium, phosphorus, and magnesium (Table 3). Potentilla acaulis Linn., with a CP content in mid-July of only $10.7 \%$, represented at most no more than $8 \%$ of forb species encountered (Spring 2000) and is a species commonly associated with habitat degradation in Inner Mongolian grasslands ( $\mathrm{Li}$ et al. 2005).

\section{DISCUSSION}

In all gazelle food habit studies Stipa, Leymus (Aneurolepidium in Jiang et al. 2002a; Elymus/Agropyron in Yoshihara et al. 2008), and Cleistogenes were the most frequently encountered 
Table 2. Levels of trace elements (parts per million) in forage and soil samples (available nutrients) at $N=54$ equidistant sample sites along northsouth transects in spring 2002.

\begin{tabular}{|c|c|c|c|c|c|c|}
\hline \multirow[b]{2}{*}{ Element } & \multicolumn{3}{|c|}{ Forage } & \multicolumn{3}{|c|}{ Soil } \\
\hline & Average \pm SD & Range & $\begin{array}{l}\text { Average } \\
\% \text { of } \min ^{1}\end{array}$ & Average \pm SD & Range & $\begin{array}{c}\text { Average } \\
\% \text { of } \min ^{2}\end{array}$ \\
\hline $\mathrm{Na}$ & $186 \pm 279$ & $120-2180$ & 37 & - & - & - \\
\hline$P$ & $1930 \pm 486$ & $1100-4000$ & 96 & $21.3 \pm 10.2$ & $10-64$ & 5 \\
\hline $\mathrm{Mg}$ & $1733 \pm 402$ & $1000-3000$ & 113 & $282 \pm 120$ & $90-633$ & 32 \\
\hline $\mathrm{Ca}$ & $5802 \pm 2352$ & $1500-14400$ & 145 & $1855 \pm 717$ & $774-3510$ & 1040 \\
\hline $\mathrm{Zn}$ & $19 \pm 3$ & $12-28$ & 94 & $0.53 \pm 0.24$ & $0.2-1.2$ & 4 \\
\hline $\mathrm{Cu}$ & $6.6 \pm 1.4$ & $4-11$ & 133 & $1.4 \pm 0.6$ & $0.4-3.0$ & $N A^{3}$ \\
\hline $\mathrm{Fe}$ & $171 \pm 68$ & $81-353$ & 571 & $23 \pm 13.0$ & 4-62 & NA \\
\hline K & $20352 \pm 4133$ & $13400-29400$ & 339 & $217 \pm 100$ & $105-636$ & 5 \\
\hline Mn & $32 \pm 8$ & $17-56$ & 316 & $5.4 \pm 3.9$ & $1.0-21.0$ & 24 \\
\hline Mo & $0.72 \pm 1.9$ & $0-13.9$ & 724 & - & - & - \\
\hline B & - & - & - & $0.50 \pm 0.24$ & $0.25-1.8$ & NA \\
\hline S & - & - & - & $10.5 \pm 5.04$ & $1-23$ & 2 \\
\hline $\mathrm{Ca}: P$ & $3.1 \pm 1.3$ & $0.53-7.6$ & 157 & - & - & - \\
\hline Ca:Mg & $3.3 \pm 1.0$ & $0.9-6.3$ & - & $7.5 \pm 4.3$ & $1.8-25.0$ & - \\
\hline Mg:K & $0.09 \pm-0.03$ & $0.05-0.2$ & - & $1.4 \pm 0.6$ & $0.6-3.9$ & - \\
\hline $\mathrm{CP}^{3}$ & $21.9 \pm 3.1$ & $15.9-30.4$ & - & NA & NA & NA \\
\hline $\mathrm{NDF}^{3}$ & $45.4 \pm 6.3$ & $30.8-58.8$ & - & NA & NA & NA \\
\hline
\end{tabular}

${ }^{1}$ The minimum nutritional requirement by animals for normal functions.

${ }^{2}$ The minimum requirement of plants for normal growth.

${ }^{3} \mathrm{NA}$ indicates not available; CP, crude protein; and NDF, neutral detergent fiber.

graminoids, and Allium spp., Astragalus spp., and Artemisia spp. were the most common forb and dwarf shrub species identified (Schaller 1998; Jiang et al. 2002a; Yoshihara et al. 2008). All three graminoids had lower mineral concentrations than the most commonly consumed forbs and dwarf shrubs, with the exception of equivalent calcium and phosphorous levels in Cleistogenes and phosphorous in Leymus. Interestingly, phosphorus and potassium concentrations in Allium were nearly twice as high as other forage species. Allium also had calcium concentrations that were three times the optimum and nearly exactly the 2:1 Ca:P ratio that is considered optimum for bone growth and lactation.
Regions abundant with forbs and shrubs that have significantly greater concentrations of calcium, phosphorous, and magnesium, particularly if they are in green flush, might be important for gazelles especially shortly before and immediately after calving. Artemisia frigida Willd. is an obviously important food source because gazelles change their digestive strategy to better digest this dwarf shrub in winter.

Murray (1995) calculated that the minimum dietary concentration of phosphorus in forage that was required by adult female wildebeest (Connochaetes taurinus) in early to midpregnancy was 1900 parts per million (ppm), but the minimum at peak lactation was $3900 \mathrm{ppm}$. The Mongolian steppe has

Table 3. Forage nutrient levels (parts per million, collected from the middle to the end of July 2002) of green forage of select species common in the eastern steppes. Values expressed in bold are below marginal levels required by animals (Van Soest 1994).

\begin{tabular}{|c|c|c|c|c|c|c|c|c|c|c|c|c|c|}
\hline Species & $\% \mathrm{CP}^{1}$ & $\mathrm{NDF}^{1}$ & $\mathrm{Ca}$ & $P$ & $\mathrm{Mg}$ & K & $\mathrm{Na}$ & $\mathrm{Fe}$ & $\mathrm{Zn}$ & $\mathrm{Cu}$ & $\mathrm{Mn}$ & Mo & $\mathrm{Ca}: \mathrm{P}$ \\
\hline Allium spp. & 25.8 & 45.4 & 7300 & 4100 & 2500 & 34800 & 160 & 179 & 37 & 6 & 29 & 0.50 & 1.8 \\
\hline Astragalus spp. & 24.0 & 29.3 & 19125 & 1800 & 3050 & 12550 & 43 & 190 & 21 & 6 & 32 & 0.23 & 10.6 \\
\hline Potentilla acaulis Linn. & 10.7 & 40.6 & 8800 & 1600 & 2700 & 9800 & 40 & 473 & 11 & 5 & 28 & 0.10 & 5.5 \\
\hline Artemisia frigida Willd. & 17.9 & 45.9 & 7457 & 2543 & 2171 & 18343 & 50 & 202 & 19 & 11 & 24 & 0.43 & 2.9 \\
\hline Caragana microphylla Lam. & 28.6 & 34.4 & 8475 & 2275 & 2750 & 16450 & 25 & 103 & 15 & 5 & 20 & 0.05 & 3.7 \\
\hline Caragana stenophylla Pojark. & 20.4 & 44.6 & 7800 & 2200 & 2100 & 14500 & 40 & 123 & 16 & 5 & 32 & 0.60 & 3.5 \\
\hline Ephedra spp. & 19.9 & 37.3 & 13500 & 2900 & 1950 & 23200 & 30 & 80 & 14 & 4 & 20 & 0.20 & 4.7 \\
\hline Stipa spp. & 15.9 & 64.0 & 4880 & 1620 & 1180 & 12080 & 39 & 177 & 18 & 7 & 32 & 0.36 & 3.0 \\
\hline Leymus chinensis (Trin.) Tzvel. & 23.1 & 53.6 & 2400 & 2200 & 1300 & 22200 & 280 & 71 & 26 & 6 & 49 & 0.40 & 1.1 \\
\hline Cleistogenes squarrosa (Trin.) Keng & 18.2 & 57.1 & 8380 & 1880 & 1760 & 14720 & 70 & 112 & 20 & 8 & 40 & 0.46 & 4.5 \\
\hline Average & 20.4 & 45.2 & 8812 & 2312 & 2146 & 17864 & 78 & 171 & 20 & 6 & 33 & 0.33 & 2.0 \\
\hline Marginal values & - & - & 4000 & 2000 & 2000 & 6000 & 500 & 30 & 20 & 5 & 10 & $<0.1$ & 2.0 \\
\hline
\end{tabular}

${ }^{1} \mathrm{CP}$ indicates crude protein; NDF, neutral detergent fiber. 
limiting forage nutrient levels that could be important for pregnant and lactating females; for example, average phosphorous concentrations fell well short of these optimum requirements. This suggests that without being selective for forage plants that have high concentrations of phosphorous, calcium, and magnesium, a gazelle would be unable to maintain phosphorus balance during peak lactation by feeding on grasses alone and would need to seek out regions where forage conditions (i.e., a high abundance of forbs and shrubs) can satisfy these needs.

\section{IMPLICATIONS}

Throughout the grasslands of Central Asia, the occurrence of Stipa is an indicator of grasslands that experience only moderate or low grazing pressure and is generally viewed as a sign of a healthy grassland ecosystem (Jiang et al. 2002a). However, Mongolia's eastern steppe makes up less than $20 \%$ of a larger East Asian grassland ecosystem that extends to approximately 1.5 million $\mathrm{km}^{2}$, and much of this region has been degraded, being converted to agriculture, being under intensive habitat management, or having experienced some other form of habitat degradation (Christensen et al. 2004). Only 1.97\% of Mongolia's steppe ecosystem is under official protection, and in light of what has happened to the rest of these grasslands, the conservation of Mongolia's remaining natural grassland should be given high priority (Reading et al. 2006).

Given the current conservation climate in Mongolia it likely will not be possible to protect the entire system, and consequently greater attention needs to be given to understanding the processes that contribute to plant diversity to aid conservation efforts directed at habitat protection. Our findings reveal the importance of regions within this ecosystem with an abundance of forbs and shrubs of high forage quality; identification of such areas will be helpful in better planning and justification of habitat conservation actions with respect to Mongolian gazelles.

\section{ACKNOWLEDGMENTS}

The authors would like to thank George B. Schaller for his invaluable direction and mentorship while conducting this study. This manuscript benefitted greatly from the attention of two anonymous reviewers.

\section{LITERATURE CITED}

Association of Official Analytical Chemists. 1999. Official methods of analysis. 16th ed. Washington, DC, USA: AOAC.

Boone, R. B., J. Lackett, K. Galvin, D. Ojima, and C. J. Tucker. 2007. Links and broken chains: evidence of human-caused changes in land cover in remotely sensed images. Environment, Science, and Policy 10:135-149.

Campbell, C. W. 1903. Journeys in Mongolia. The Geographic Journal 22:485-518.

Christensen, L., M. Coughenour, J. Ellis, and Z. Chen. 2004. Vulnerability of the Asian typical steppe to grazing and climate change. Climate Change 63:351-368.

ERdensaikhan, N., And M. ERdentuya. 2002. Fire situation in Mongolia. International Forest Fire News 26:75-83.

Grubov, V. I. 1982. Key to the vascular plants of Mongolia (with the atlas). Leningrad, Russia: Russian Academy of Science. 442 p. (In Russian)
Gunin, P., E. A. Vostokova, N. I. Dorofeyuk, P. E. Tarasov, and C. C. Black. 1999. Assessing present day plant cover dynamics. In: P. Gunin, E. A. Vostokova, N. I. Dorofeyuk, P. E. Tarasov, and C. C. Black [EDS.]. Vegetation dynamics of Mongolia. Dordrecht, Netherlands: Kluwer Academic Publishers. p. 131-163.

Hu, S., D. Hannaway, and H. Youngberg. 1992. Forage resources of China. Wageningen, Netherlands: Centre for Agricultural Publishing and Documentation. $327 \mathrm{p}$.

Humphrey, C., and D. Sneath. 1999. The end of nomadism? Society, state and the environment in Inner Asia. Durham, NC, USA: Duke University Press. $355 \mathrm{p}$.

Ito, T. Y., N. Miura, B. Lhagvasuren, D. Enkhbileg, S. Takatsuki, A. Tsunekawa, and Z. JiAng. 2005. Preliminary evidence of a barrier effect of a railroad on the migration of Mongolian gazelles. Conservation Biology 19:945-948.

Ito, T. Y., N. Miura, B. Lhagvasuren, D. Enkhbileg, S. Takatsuki, A. Tsunekawa, and Z. JIAng. 2006. Satellite tracking of Mongolian gazelles (Procapra gutturosa) and habitat shifts in their seasonal ranges. Journal of Zoology 269:291-298.

Jiang, Z. W., S. Takatsuki, J. LI, W. Wang, Z. GaO, and J. Ma. 2002a. Seasonal variations in foods and digestion of Mongolian gazelles in China. Journal of Wildlife Management 66:40-47.

Jiang, Z. W., S. Takatsuki, J. LI, W. Wang, J. Ma, and Z. Gao. 2002b. Feeding type and seasonal digestive strategy of Mongolian gazelles in China. Journal of Mammalogy 83:91-98.

Jiang, Z. W., S. Takatsuki, W. Wang, J. LI, K. Jin, and Z. Gao. 2003. Seasonal changes in parotid and rumen papillary development in Mongolian gazelle (Procapra gutturosa Pallas). Ecological Research 18:65-72.

Kawamura, K., T. Akiyama, O. Watanabe, H. Hasegawa, F. Zhang, H. Yokota, and S. WANG. 2003. Estimation of aboveground biomass in Xilingol Steppe, Inner Mongolia using NOAA NDVI. Grassland Science 49:1-9.

LI, J., Z. LI, AND J. REN. 2005. Effect of grazing intensity on clonal morphological plasticity and biomass allocation patterns of Artemesia frigida and Potentilla acaulis in the Inner Mongolian steppe. New Zealand Journal of Agricultural Research 48:57-62.

McNaughton, S. J. 1988. Mineral nutrition and spatial concentrations of African ungulates. Nature 334:343-345.

McNaughton, S. J. 1990. Mineral nutrition and seasonal movements of African migratory ungulates. Nature 345:613-615.

Mueller, T., K. A. Olson, T. K. Fuller, G. B. Schaller, M. G. Murray, and P. LeImgruber. 2008. In search of forage: predicting dynamic habitats of Mongolian gazelles using satellite-based estimates of vegetation productivity. Journal of Applied Ecology 45:649-658.

Murray, M. G. 1995. Specific nutrient requirements and migration of wildebeest. In: A. R. E. Sinclair and P. Arcese [EDS.]. Serengeti II: research, management, and conservation of an Ecosystem. Chicago, IL, USA: University of Chicago Press. p. 231-256.

National Research Council. 1985. Nutrient requirements of sheep. Washington, DC, USA: National Academy Press. $99 \mathrm{p}$.

$\mathrm{N}$, J. 2004. Estimating net primary productivity of grasslands from field biomass measurements in temperate northern China. Plant Ecology 174: 217-234.

OLson, K. A. 2008. Distribution and ecology of Mongolian gazelles (Procapra gutturosa Pallas 1777) in Mongolia's eastern steppe [dissertation]. Amherst, MA, USA: University of Massachusetts, Amherst. $140 \mathrm{p}$.

Olson, K. A., T. K. Fuller, T. M. Mueller, M. Murray, C. Nicolson, D. Odonkhuu, S. Bolortsetseg, and G. B. Schaller. 2010. Annual movements of Mongolian gazelles: nomads in the eastern steppe. Journal of Arid Environments. Available at: http://dx.doi.og/10.1016/j.jaridenv.2010.05.022. Accessed 5 August 2010.

Olson, K. A., T. K. Fuller, G. B. Schaller, B. Lhagvasuren, and D. Odonkhuu. 2005 a. Reproduction, neonatal weights, and first-year survival of Mongolian gazelles (Procapra gutturosa). Journal of Zoology 265:227-233.

Olson, K. A., T. K. Fuller, G. B. Schaller, D. Odonkhuu, and M. G. Murray. 2005b. Estimating the population density of Mongolian gazelles Procapra gutturosa by driving long-distance transects. Oryx 39:164-169.

Olson, K. A., T. M. Mueller, S. Bolortsetsteg, P. Leimgruber, W. F. Fagan, and T. K. Fuller. 2009a. A mega-herd of more than 200000 Mongolian gazelles procapra gutturosa: a consequence of habitat quality. Oryx 43:149-153. 
Olson, K. A., T. M. Mueller, P. Leimgruber, C. Nicolson, T. K. Fuller, S. Bolortsetseg, A. E. Fine, B. Lhagvasuren, and W. F. Fagan. 2009b. Fences impede long-distance Mongolian gazelle movements (Procapra gutturosa) in drought-stricken landscapes. Mongolian Journal of Biological Sciences 7:45-50.

Reading, R. P., D. J. Bedunah, S. Amgalanbaatar. 2006. Conserving biodiversity on Mongolian rangelands: implications for protected area development and pastoral uses. In: D. J. Bedunah, E. Durant Mcarthur, and M. Fernandez-Gimenez [COMPS]. 2006. Rangelands of Central Asia: Proceedings of the conference on transformations, issues, and future challenges; 24-30 January 2004. Salt Lake City, UT, USA: US Department of Agriculture, Forest Service, RMRS-P39. p. 1-17.

Schallek, G. B. 1998. Wildlife of the Tibetan Steppe. Chicago, IL, USA: University of Chicago Press. 373 p.

SutrIE, J. 2005. Grazing management in Mongolia. In: J. Suttie, S. Reynolds, and C. Batello [EDS.]. Grasslands of the world. Rome, Italy: Food and Agriculture Organization of the United Nations. $514 \mathrm{p}$.

Underwood, E., and N. Suttie. 1999. The mineral nutrition of livestock. 3rd ed. Wallingford, Oxon, United Kingdom: CAB International. 614 p.

Van Soest, P. J. 1994. The nutritional ecology of the ruminant. 2nd ed. Ithaca, NY, USA: Cornell University Press. $476 \mathrm{p}$
Van Soest, P. J., J. B. Robertson, and B. A. Lewis. 1991. Methods for dietary fiber, neutral detergent fiber, and nonstarch polysaccharides in relation to animal nutrition. Journal of Dairy Science 74:3583-3597.

Wilmshurst, J. F., J. M. Fryxell, B. P. Farm, A. R. E. Sinclair, and C. P. Henschel. 1999. Spatial distribution of Serengeti wildebeest in relation to resources. Canadian Journal of Zoology 77:1223-1232.

Wingard, J. R., And P. ZahleR. 2006. Silent steppe: the illegal wildlife trade crisis in Mongolia. Mongolia Discussion Papers, East Asia and Pacific Environment and Social Development Department. Washington, DC, USA: The World Bank. $163 p$.

Yoshihara, Y., T. Y. Ito, B. Lhagvasuren, and S. Takatsuki. 2008. A comparison of food resources used by Mongolian gazelles and sympatric livestock in three areas in Mongolia. Journal of Arid Environment 72:48-55.

Yu, F., K. Price, J. Ellis, J. Feddema, And P. Shi. 2004a. Interannual variations of the grassland boundaries bordering the eastern edges of the Gobi Desert in Central Asia. International Journal of Remote Sensing 25:327-346.

Yu, F., K. Price, J. Ellis, and D. Kastens. 2004b. Satellite observation of the seasonal vegetation growth in Central Asia: 1982-1990. Photogrammatic Engineering and Remote Sensing 70:461-469.

Zou, C., K. Wang, T. Wang, And W. Xu. 2007. Overgrazing and carbon soil dynamics in east Inner Mongolia of China. Ecological Research 22:135-142. 